\title{
Academics' Opinions on Organizational Democracy and the Perception of Academic Freedom and the Appropriate Level in Turkey
}

\author{
Süheyla Bozkurt ${ }^{1} \&$ Ali Balc1 $^{2}$ \\ ${ }^{1}$ Department of Education Science, Cankiri Karatekin University, Cankiri, Turkey \\ ${ }^{2}$ Department of Education Science, Ankara Universty, Ankara, Turkey \\ Correspondence: Süheyla Bozkurt, Department of Education Science, Cankiri Karatekin University, Faculty of \\ Art, Cankiri, Turkey. Tel: 90-505-803-1292. E-mail: sbozkurtmagic@ hotmail.com
}

Received: December 30, 2019

Accepted: March 7, 2020 Online Published: March 20, 2020

doi:10.5539/hes.v10n2p95

URL: https://doi.org/10.5539/hes.v10n2p95

\begin{abstract}
The study aimed to determine how lecturers have adopted organizational democracy and academic freedom in Turkish state universities, as well as to find out their views on its appropriation for Turkey. A correlative descriptive survey model is used in this study. The study sample was included 418 academics working at state universities in Ankara. For this research, an 'Organizational Democracy Scale' and an 'Academic Freedom Scale' were developed and employed by the researcher, and the obtained data were analyzed using SPSS statistical software. The arithmetic mean and the standard deviation were calculated for the answers provided by the academics. Regression analysis was conducted to find out the effect of organizational democracy on academic freedom. In the qualitative phase of the study, face-to-face interviews were conducted with 20 academics. NVivo 10 software was used to analyze the content of the interviews. At the end of the study, it was found that university administrations should avoid discriminative attitudes; should account for their decisions and implementations; deans and faculty boards should be elected democratically; all stakeholders (apart from academics), including students, should take part in both elections and be involved in management processes; and finally, the election system should be more democratic.
\end{abstract}

Keywords: organization democracy, academic freedom, accountability, autonomy, higher education

\section{Introduction}

Historically, from the time when the first university was founded, the issue of 'how to design democratic and academic freedom at universities' has been debated. Universities are affected by social, economic, cultural, and administrative structures; therefore, the concepts of democratic and academic freedom at universities are described according to the perception of that era. In other words, the concepts of democratic and academic freedom are described in different ways for different ages.

To debate organizational democracy, it is first necessary to describe the sub-terms of democracy and organization. Organizational democracy is described in the universities, as 'giving the university academics equal rights in decision making' (Olsen, 2007). The prerequisite for democratic life at universities is an electoral system, yet running democratic elections does not automatically make the university a democratic university (Olsen, 2007). Academic freedom is considered as a 'negative right,' which means the government or overseeing authority does not interfere with individual rights (Kepenekçi, 2000). Akerlind and Kayrooz (2003), who also consider that academic freedom is a negative right, describe it as 'the right of academics to research, examine, explain, and debate scientific problems according to professional, ethical principles without interference from political and/or religious authorities.' This definition emphasizes that academic freedom is far removed from any intervention.

Moreover, many researchers (MacGee \& Block, 1997; Tight, 1998; Taylor, 2001) describe academic freedom as a suitable environment in which academics can properly conduct their research. For example, O'Hear (1988) describes academic freedom as academic activities within higher education institutions and the responsibility of higher education institutions to support academic activities that provide academic freedom. Academic freedom is seen as a provision of a suitable environment for academic activities, i.e., the concept is described as a positive right rather than a negative right. This study researched the views of Turkish academics on the concepts of organizational democracy and academic freedom. 
As mentioned above, universities are evolving systems affected by the social, economic, and cultural structures of their periods (Wissema, 2009). Historically, universities have been affected by different parameters, and as a result, different models for managing universities have emerged as the functions of universities have changed. In the classical perception of universities, they have two roles: producing science and training professionals (Özdem \& Sarı, 2008). However, modern universities have to expand their ability to obtain new information in different ways (Emery, 1993). In today's world, one of the aims of universities is to generate profit by transforming themselves into 'Entrepreneurial Universities.' Entrepreneurial universities aim to create their resources by which means they can distance themselves from economic pressures and remain autonomous. However, some universities, while creating their resources, may neglect the public interest, as they become part-managed by the companies that provide their financial support (Bok, 1993).

The concepts of 'university and democracy' suggest a very close functional and structural relationship. The function of universities is to research freely, and freedom appears where democratic structures exist. Universities have built democratic structures by giving rights to academics in decision-making and promotions, as well as establishing autonomous mechanisms. The functions of universities must be redefined to establish mechanisms for participation and autonomy, and the management structures and autonomy in relations should be rebuilt, not only within Turkey but worldwide. It can be seen that the functions of universities in Turkey have changed in recent times, with universities transforming from the classical model to entrepreneurial universities.

Considering understand how organizational democracy and academic freedom have developed at universities in Turkey, it is necessary to examine the managing model, processes, and income resources of universities. Higher education in Turkey has been based on Article 130 and 131 of the Turkish Constitution and Higher Education Law No. 2547. Article 130 states that universities are public entities with scientific freedom. Additionally, it is stated that universities can be founded both by the state and also by non-profit making foundations under state control and inspection. The basic structures of Turkish universities are based on the principles of the Anglo Saxon Model of Civil Law of Continental Europe and Higher Education Law No. 2547.

In-Law No. 2457, it is stated that a public entity rules all the universities and autonomous institution called the 'The Council of Higher Education' that organizes all higher education in Turkey and directs all activities of every university. The Council of Higher Education in Turkey (CHET) is autonomous in making decisions relating to higher educational institutions and also has the right to implement decisions without the need for approval from any political office. Law No. 2547 organizes the management of universities around three main bodies: The Rector, The Senate, and The University Administrative Board. According to Law No. 2547, the senate supports the rector in academic issues, while the university administrative board supports the rector with managerial issues. The senate and the university administrative board have no direct right to make decisions. In Turkey, the rector has the right to make decisions and implement them in the university. As can be seen here, the university structure is designed according to the 'Bureaucratic Organization Approach'.

Article 13 of Law No. 2547 provides three steps for the election of rectors. In the first step, the names of the six candidates who achieve the highest number of votes are sent to CHET. In the second step, the Board of CHET chooses three of these six rectoral candidates, and in the final step, the President of the Republic of Turkey chooses one of these three as the rector. In universities established by foundations, there is no three-step decision; instead, a board of trustees chooses the rector directly. It should be noted that the authority of rectors is very broad and may result in a 'one-man system.' In addition to this, rectors are chosen by the President; it could be argued that rectors are the representatives of the state.

In-Law No. 2547, the income resources of higher educational institutions are defined as budget appropriations, private income, and revolving funds. Besides this, according to the same Law, higher educational institutions are exempt from some taxes, fees, and expenditures as recipients and users of these income sources. Therefore, as a result, they also realize some indirect income resources. In addition to this, from this Law, higher education institutions are obliged to use their incomes rationally, efficiently, and economically. According to Article 130 of the Turkish Constitution, after universities prepare their budget, they submit the draft budget to CHET, which then examines and checks it. The budget is then presented to the Ministry of National Education (MoNE). Finally, the budget is implemented and controlled according to the principles of central management budgeting (İlyas, 2012).

The primary income source of higher education institutions are public funds; in other words, budgetary appropriations. In the 1980s, the proportion of budget appropriations to total income was approximately $80 \%$. With time it has reduced, and today budget appropriations make up approximately 55-60\% of income. The main reason for this move away from central budgetary funding has been the rise of revolving funds as an income 
source. The level of revolving funds compared to the total budget was about $20 \%$ in the 1990 s, whereas now that rate has increased to $30 \%$. The same rate of change has also been seen in terms of private income. In the 1990s, the rate of private income was about 4\%, whereas today, it is over 10\% (İlyas, 2012).

In-Law No. 2547, the management of higher education is both centralized and bureaucratic; therefore, universities and their related sub-units have no managerial autonomy (Dölen, 2010). Law No. 2547 gives CHET the broad authority to interfere in both the managerial and financial issues of universities, resulting in a high level of management (Yavuz, 2012). Importantly, Law No. 2547, also provides that nobody, apart from associates, has the right to participate in managerial issues. This current study, therefore, examines how organizational democracy and academic freedom are constructed in universities that are based on Bureaucratic Organization.

\subsection{Purpose of the Study}

The concepts of academic freedom and organizational democracy are affected by variables such as the general attitudes of academics, their teaching methods, research and evaluation, organization of scientific branches, university managerial structure, tenure, institutional autonomy, academic structure and application, and social value judgments. In this respect, this study aims to put forward academics' points of view on how the concepts of organizational democracy and academic freedom, are adopted and appropriated to Turkish universities. For this purpose, we tried to answer the following research questions within this study.

1. What do academics at Turkish state universities think about the perceptions and appropriation of organizational democracy and academic freedom?

2. Does the appropriation level of organizational democracy predict the appropriation level of academic freedom?

3. What are the opinions of academics regarding the barriers to organizational democracy and academic freedom? What is their suggestion about these barriers?

\section{Method}

Descriptive statistics used to describe the existing situation in this study, i.e., the academics' views on organizational democracy and academic freedom and their appropriation in Turkish universities. The study conducted as a mixed model, where both qualitative and quantitative research methods were applied together.

\subsection{Population and Sample}

The target population of the quantitative part of the study consisted of academics working at Ankara University, Hacettepe University, and Gazi University, in the Faculty of Education, Faculty of Engineering, or Faculty of Medicine; all of which located in Ankara, the capital of Turkey. It noted that 396 academics who represent a total population of 4,144 is adequate to achieve statistical significance, with $\mathrm{p}=0.05$ (Balc1, 2001).

In the research, a stratified sampling method employed. In this respect, 'university,' 'faculty,' and 'title' were the variables selected as sampling criteria, and academics, therefore, have chosen from three universities, three faculties, and four professional grades, by way of random sampling. Four hundred thirty questionnaires were delivered, and 418 returned. Eight questionnaires were later removed from the evaluation as they were incomplete. In the qualitative part of the study, data collected from 20 people (five from each professional grade) by interview.

\subsection{Data Collecting Tools}

To collect data, the 'Organizational Democracy and Academic Freedom' scale was developed by the researchers. In the development phase of the scale, literature about organizational democracy and academic freedom was examined and interviews were conducted with the academics. At the end of these two procedures, a draft scale form was prepared. The draft scale was sent to 21 academics to get feedback. The scale is graded according to a 5-point Likert-type scale, ranging from 'disagree' to 'completely agree'. The limit of the points and their weights were: 'completely agree' $=5$, limits 4.20-5.00; 'strongly agree' $=4$, limits 3.40-4.19; 'moderately agree' $=3$, limits 2.60-3.39; 'slightly agree' $=2.00$, limits 1.80-2.59; and 'disagree' $=1.00$, limits 1.00-1.79 (Balc1, 2001).

The draft scale was sent to 101 academics for completion. The collected data was analyzed for Kaiser Meyer-Olkin (KMO) coefficient and Bartlett Sphericity test for confirmatory factor analysis. The KMO coefficient for the Organizational Democracy Scale was found to be .83, and the Bartlett Sphericity value was significant at the level of $\mathrm{p}<.05$. The KMO coefficient for the Academic Freedom Scale was found to be .87 , and the Bartlett Sphericity value was meaningful at the level of $p<0.05$. The structural validity of the scales was accomplished with confirmatory factor analysis, and reliability analysis was performed using the Cronbach 
Alpha coefficient.

To determine the subcategories of the scales, the Varimax vertical revolving method was used. Besides, eigenvalue and screen plot were employed. At the end of the analyses, it was seen that the Organizational Democracy Scale had two factors, and the Academic Freedom Scale had three factors. In the Organizational Democracy Scale, it was found that two factors explained $44.77 \%$ of the total variation, and in the Academic Freedom scale, three factors explained $58.12 \%$ of the total variation. In both the Organizational Democracy Scale and the Academic Freedom Scale, the factor weights of the whole items were greater than 0.35 . In addition to this, to determine the discriminates of the items of the subcategories, the total item correlation was calculated. The validity and reliability analysis results of the Organizational Democracy Scale and the Academic Freedom Scale are shown in Table 1.

Table 1. Validity and reliability: Organizational democracy and academic freedom scales

\begin{tabular}{|c|c|c|c|c|c|}
\hline Scale & Subcategories & $\begin{array}{c}\text { Item } \\
\text { number }\end{array}$ & $\begin{array}{c}\text { Explained } \\
\text { variation }\end{array}$ & $\begin{array}{l}\text { Total item } \\
\text { correlation }\end{array}$ & $\begin{array}{c}\text { Cronbach } \\
\text { Alpha }\end{array}$ \\
\hline Organizational & Participation & 19 & 32.83 & $.31-.60$ & .91 \\
\hline Democracy & Autonomy & 11 & 11.94 & $.52-.22$ & .81 \\
\hline \multirow[t]{3}{*}{ Academic Freedom } & Instruction & 5 & 13.19 & $.51-.36$ & .76 \\
\hline & Research & 4 & 9.32 & $.62-.13$ & .63 \\
\hline & Publication & 18 & 35.61 & $.77-.50$ & .94 \\
\hline
\end{tabular}

In the qualitative part of the research, a semi-structured interview form was developed. To determine the questions on the form, the Organizational Democracy and Academic Freedom scale and its subcategories were taken into consideration. The form consisted of 16 open-ended questions.

In addition to this, the normal distribution of the collected data via the Organizational Democracy Scale (ODS) was analyzed with scatter diagrams and descriptive statistics. The average of the collected data was 2.97 , the median of the data was 2.90 , and the coefficient of skewness was .34, and the coefficient of kurtosis was .33 . The mean of the collected data with Academic Freedom Scale (AFS) was 3.41, the median of the data was 3.38, and the coefficient of skewness was .06, and the coefficient of kurtosis was .61. When the coefficients of skewness and kurtosis are under 1 , and the median and average are very close to each other, it means the data is normally distributed.

To examine whether the collected data verified the factorial structure based on the literature, Confirmatory Factor Analysis (CFA) was used. To conduct this analysis, Lisrel 8.8. program was used. To evaluate the convenience of the model that verified with CFA requires many fix indices. In this second-order CFA analysis, the fix indices were used: Chi-Square Goodness of Fit $\chi 2$, Comparative Fit Index -CFI, Normed Fit Index -NFI, Not Normed Fit Index -NNFI, Standardized Root Mean Square Residuals -SRMR and Root Mean Square Error of Approximation -RMSEA. The margin of error was .05. Confirmatory Factor Analysis was an effective analysis in the first phases of scale development (Şimşek, 2007). In the analysis results for the ODS, $\chi^{2}=$ $2000.88(\mathrm{sd}=404, \mathrm{p}>.05)$ and $\chi 2 / \mathrm{sd}$ value was 4.95 . Moreover, in the analysis results for the AFS, $\chi 2=1002.90$ $(\mathrm{sd}=272, \mathrm{p}>.05)$ and $\chi 2 / \mathrm{sd}$ value was 3.68. In small samplings, if the value was less than or equal to 2.5 , it means "perfect fit"; if the value was less than or equal to 5, it means "good fit" (Kline, 2005; Tabachnick, 2001). In this study, the values were 4.95 and 3.68 , and according to the value and the literature, it can be said that factor structure has a good fit. When other fix indices were examined, the RMSEA value was .01 for the ODS and .04 for the AFS. To Jöroskog and Sörbom (1993), if the RMSEA value is less than .05, it means the structure has a perfect fit; if the value is between .05 and .08, it means the structure has a good fit (Jöreskog, 1993). According to this expression, the structures of the two scales have a perfect fit. It can be observed that the SRMR value is 0.079 for the ODS and 0.065 for the AFS. If SRMR value is less than .05 , it means the structure has a perfect fit (Brown, 2006) and if the value is less than .10, it means the structure has a weak fit (Çokluk, Şekercioğlu, \& Büyüköztürk, 2010). In this context, the structures of both scales have a perfect fit according to SRMR value. Finally, NFI value was .92 , NNFI was .93, and CFI was .93 for the ODS and respectively $.96, .97$ and .97 for the AFS. If NFI, NNFI, and CFI values are greater than .95 , it means "perfect fit," and between .95 and .90, it means "good fit" (Sümer, 2000). The fit indices of the model show that the values for the ODS, there was a good fit and perfect fit for the AFS. 


\subsection{Data Analysis}

To analyze the quantitative part of the research, SPSS (Statistical Package for Social Sciences) version 17 was used. The arithmetic mean of academics' answers to the items on the scale was calculated in order to discover the academics' points of view on the concepts of organizational democracy and academic freedom and their perception and appropriation levels in Turkish universities. Additionally, regression analysis was performed to determine the relationship between organizational democracy and academic freedom.

In the qualitative part of the study, the NVivo 10 program was used, and text content analysis performed. The interviews with the academics were transcribed and, according to the sub-questions of the study, examined and logical categories were determined. The coding was applied as free codes. After that, according to their aspects, each was categorized, and for their themes, tree node coding was used. From the transcripts, 105 codes were identified. In order to check the conformity of the codes and themes, the researchers requested two experts to study the transcripts and themes separately. The exercise resulted in an agreement for 100 of the 105 codes.

The reliability of the qualitative research was calculated based on the formula of Miles and Huberman (1994): Compromise Percentage $=($ Agreement codes/Agreement Codes + Disagreement Codes $) \times 100$. By using this formula, the reliability rate was found to be $95 \%$. In addition to this, quotations have been frequently added in support of the findings.

\section{Results}

\subsection{Organizational Democracy and Academic Freedom}

In Table 2, the arithmetic means of the answers given by academics on the Organizational Democracy and Academic Freedom scale and its respective subcategories are shown based on the academics' opinions on the concepts of organizational democracy and academic freedom, and their perception and appropriation levels at Turkish universities.

Table 2. Arithmetic mean: The views of Turkish academics on the concepts of organizational democracy and academic freedom, their perception and appropriation levels

\begin{tabular}{lcc}
\hline & Perception Level $(\overline{\mathrm{X}})$ & Appropriation Level in Turkey $(\overline{\mathrm{X}})$ \\
\hline Subcategories of Organizational Democracy & & \\
Participation & 4.23 & 2.96 \\
Autonomy & 3.36 & 2.28 \\
Subcategories of Academic Freedom & & \\
Instructional Freedom & 4.38 & 3.20 \\
Research Freedom & 4.06 & 2.91 \\
Publication Freedom & 4.11 & 2.95 \\
\hline
\end{tabular}

As seen in Table 2, academics fully perceived the organizational democracy subcategory of participation $(\bar{X}=4.23)$, with moderate level appropriation $(\overline{\mathrm{X}}=2.96)$, and the autonomy subcategory perception level was also moderate $(\overline{\mathrm{X}}=3.36)$, with slight appropriation in Turkey $(\overline{\mathrm{X}}=2.28)$. Academics completely perceived the academic freedom subcategory of instructional freedom $(\overline{\mathrm{X}}=4.38)$, and higher perceived the other subcategories of research freedom $(\overline{\mathrm{X}}=4.06)$ and publication freedom $(\overline{\mathrm{X}}=4.11)$. Besides, they found the whole category of academic freedom appropriation in Turkey to a moderate level $\left(\overline{\mathrm{X}}_{\text {instruction }}=3.20 ; \overline{\mathrm{X}}_{\text {research }}=2.91 ; \overline{\mathrm{X}}_{\text {publication }}=2.95\right)$.

\subsection{Results Related to the Regression of Organizational Democracy on Academic Freedom}

The results related to regression of appropriation for the subcategories of organizational democracy (participation and autonomy) on the appropriation of the subcategories of academic freedom (instructional, research, and publication freedom) are shown in Table 3. 
Table 3. Regression analysis: Relationship between appropriations of organizational democracy on appropriation of academic freedom

\begin{tabular}{|c|c|c|c|c|c|c|c|}
\hline Variables & B & Standard Error $_{B}$ & B & $\mathrm{T}$ & $\mathrm{P}$ & Dual $\mathrm{r}$ & Partial r \\
\hline Constant & 1.85 & .223 & & 8.31 & .00 & & \\
\hline Participant & .54 & .05 & 0.48 & 10.93 & .00 & .50 & 47 \\
\hline Autonomy & .06 & .04 & 0.06 & 1.39 & .16 & .21 & .06 \\
\hline $\begin{array}{lr}R=.51 \quad R^{2}= \\
F_{(2.407)}=72.05\end{array}$ & $\begin{array}{l}.26 \\
\mathrm{p}=.00\end{array}$ & & \multicolumn{5}{|c|}{ Dependent variable: Instructional Freedom } \\
\hline Constant & 1.57 & .24 & & 6.39 & .00 & & \\
\hline Participant & .52 & .05 & 43 & 9.46 & .00 & .45 & .42 \\
\hline Autonomy & .08 & .05 & .07 & 1.66 & .09 & .20 & .08 \\
\hline $\begin{array}{l}\mathrm{R}=.46 \\
\mathrm{~F}_{(2.407)}=56.19\end{array}$ & $\begin{array}{l}\mathrm{R}^{2}=.21 \\
\mathrm{p}=.00\end{array}$ & & \multicolumn{5}{|c|}{ Dependent variable: Research Freedom } \\
\hline Constant & 1.28 & .218 & & 5.90 & .00 & & \\
\hline Participant & .60 & .04 & .53 & 12.32 & .00 & .55 & .52 \\
\hline Autonomy & .08 & .04 & .07 & 1.82 & .07 & .24 & .09 \\
\hline $\begin{array}{l}\mathrm{R}=.56 \\
\mathrm{~F}_{(2.407)}=93.11\end{array}$ & $\begin{array}{l}\mathrm{R}^{2}=.31 \\
\mathrm{p}=.000\end{array}$ & & \multicolumn{5}{|c|}{ Dependent variable: Publication Freedom } \\
\hline
\end{tabular}

As seen in Table 3, there was a statistically significant relationship at a low level between participant and autonomy, and instructional freedom $\left[\mathrm{R}_{\text {(instruction) }}=.51, \mathrm{~F}_{(2.407)}=72.05, \mathrm{p}<.05\right]$. These findings indicated that participation and autonomy dimensions could explain about $26 \%$ of instructional freedom $\left(\mathrm{R}^{2}=.26\right)$.

There was a significant relationship at a low level between participant and autonomy dimensions, and research freedom $\left[\mathrm{R}_{(\text {research })}=.46, \mathrm{~F}_{(2.407)}=56.11, \mathrm{p}<.05\right]$. This finding showed that participation and autonomy dimensions could explain about $21 \%$ of research freedom $\left(\mathrm{R}^{2}=.216\right)$.

There was a meaningful relationship at a moderate level between participant and autonomy dimensions, and publication freedom $\left[\mathrm{R}_{\text {(publication) }}=.46, \mathrm{~F}_{(2.407)}=56.11, \mathrm{p}<.05\right]$. This finding proved that participation and autonomy dimensions could explain about $31 \%$ of publication freedom $\left(\mathrm{R}^{2}=.314\right)$.

\subsection{Result and Interpretations Related to the Obstacles in Organizational Democracy and Academic Freedom and What Should be done}

The questions -"What are the obstacles in organizational democracy and academic freedom?" and "What should be done to put into practice organizational democracy and academic freedom?"- were put to the academics.

The categories and frequencies of these categories generated from academics' answers about the obstacles in organizational democracy are shown in Figure 1.

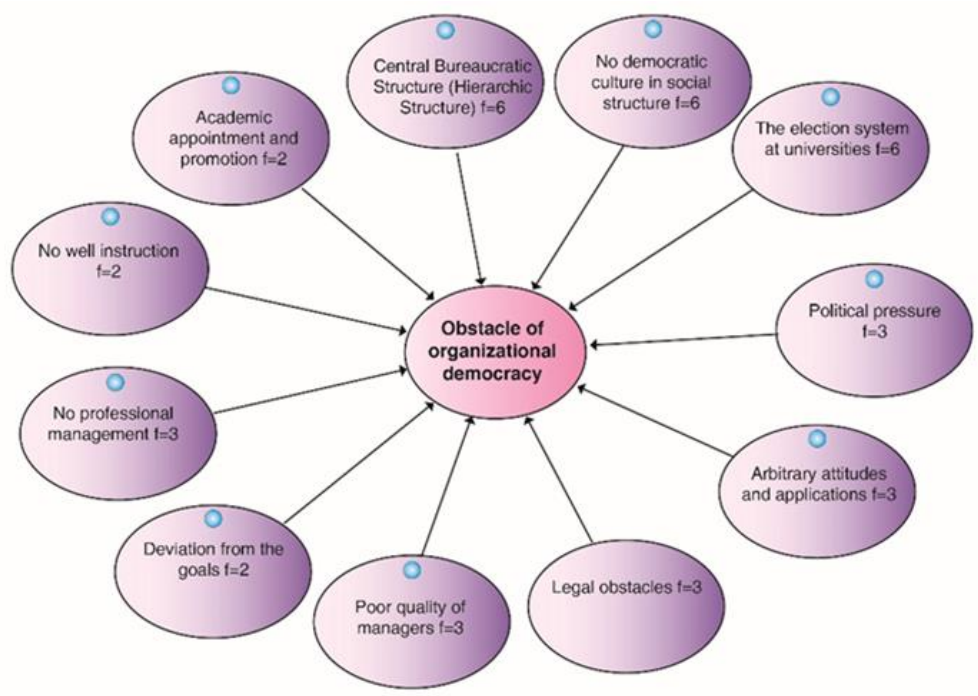

Figure 1. Obstacles in organizational democracy for academics 
The academic's views on the central bureaucratic structure, lack of democratic culture in social structure, and the electoral system at universities:

"...democracy is not an appropriate term when talking about the election of those who manage the universities. In the election of rectors, firstly CHET, then the President is involved and is therefore not a democratic process. The process of election of rectors is incompatible with the spirit of democracy. Of course, managers have to be elected, but these elections need to be compatible with the spirit of democracy. The right of election was not only given to associate/ professors but also to teaching assistants, lecturers, and other experts. Giving the right of the election just to associates was incompatible with organizational democracy..." AGE2.

The categories and frequencies of these categories generated from the teaching assistants' answers about the applicability of organizational democracy are shown in Figure 2.

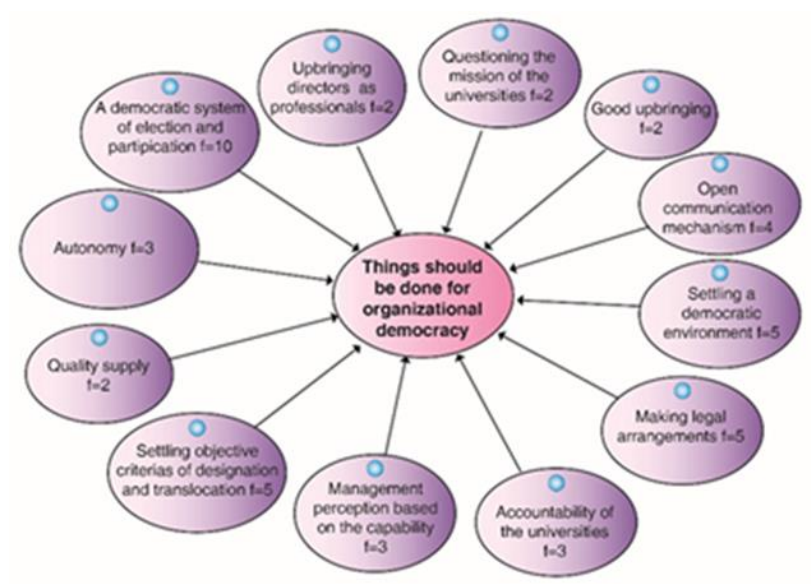

Figure 2. Organizational democracy: What should happen (according to academics)

A teaching assistant expressed his/her thoughts about what should be done about the applicability of organizational democracy.

“...Elections at universities have divided academics. During the election period, we feel unnecessarily detached. New criteria were determined for all processes, from the process of project preparation to the appointment of academics. We became democratic in terms of tackling issues like 'I did not get the position, in spite of being here five years' or 'the position went to someone they wanted' or 'five academics passed the associate professorship exam, but look who got the position'. If there was a system that would support the success of all academics, instead of just those academics considered very close to managers, we would better resemble a true democracy. The system should be based on competence, accountability, and clear application..." YDK3.

The categories and frequencies of these categories generated from academics' answers about the obstacles to academic freedom are portrayed in Figure 3.

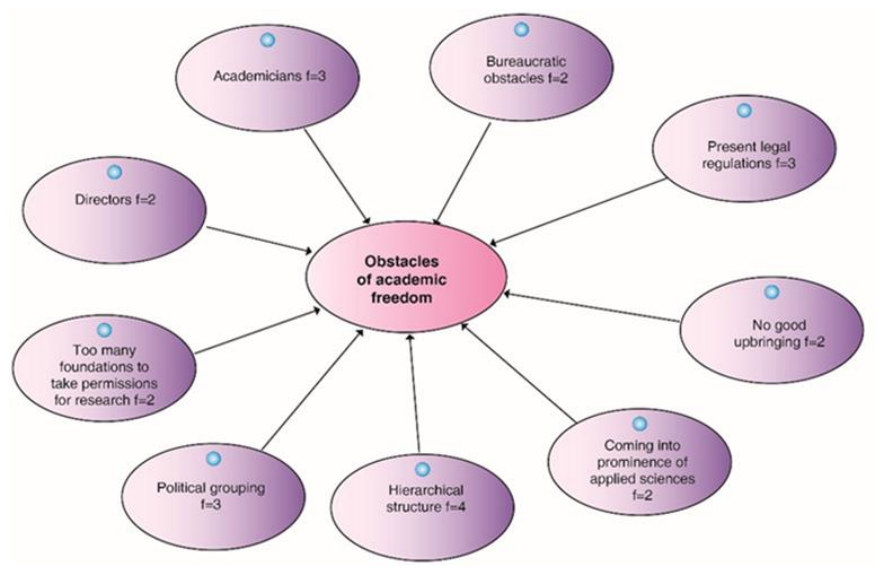

Figure 3. Obstacles to academic freedom for academics 
Academics gave their opinion about obstacles to academic freedom, as shown below.

"...The most important problem we have is the hierarchy of the academic world and the result of this hierarchy, the inspection mechanism. Academic freedom cannot exist alongside these mechanisms. However, the structure of universities was based on a hierarchic structure and our workplace was subsequently based on this hierarchic structure. In a hierarchic structure, if you have a higher rank or title, you can oppress your lower-ranking colleagues, or if you have higher managerial status, you can oppress others without managerial status. By using rank, title and managerial position, these actions become legal. In an academic world, these oppressions should not exist. If the academic world resisted 'oppression through the hierarchy,' there would not be these problems. When academic society integrates with hierarchic structure and normalizes this structure, you cannot have academic freedom. You can easily see this hierarchic structure in action in the determination of themes for theses, the defense of theses, the publication period, academic appointments, given positions..." PK2.

The categories and frequencies of these categories generated from academics answers about the applicability of academic freedom are shown in Figure 4.

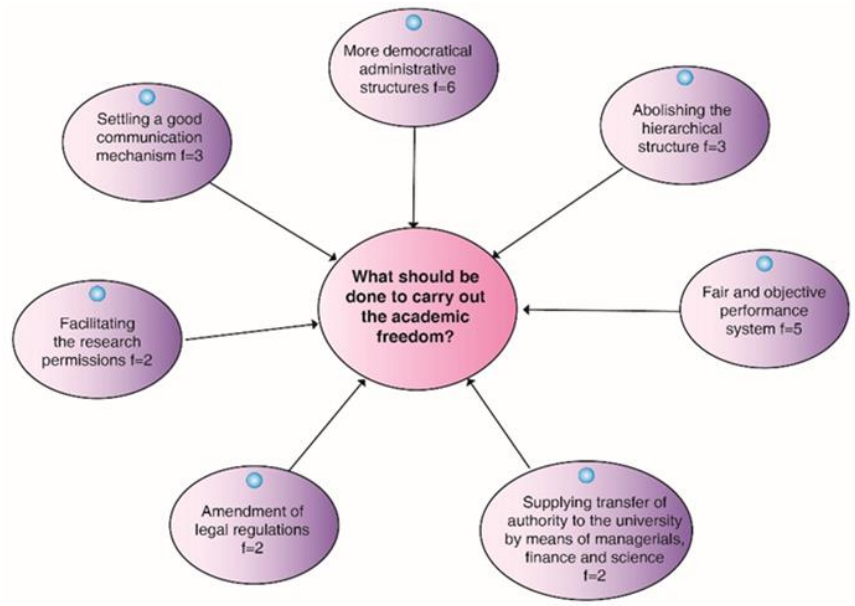

Figure 4. Academic freedom: What should be done (according to academics)

The academics gave their opinion about the applicability of academic freedom as:

“...To have academic freedom at universities, managers should put in place certain, clear and achievable targets; support academic research and publication; create an open environment; open communication channels; identify clear criteria about appointments and assignments; encourage cooperation between academics. The culture and the climate of universities are suitable for these..." DE1.

\section{Discussion}

This study aimed to put forward academics' views on how the concepts of organizational democracy and academic freedom were perceived and appropriated in Turkish universities. The research showed that academics believe that they should be selected for faculty councils and positions via democratic election. This finding showed that the electoral system is considered one of the most important methods of participation at universities. In this study, it was also concluded that democratic processes at universities require not only elections but also that academics' opinions on applications and decision making to be taken into account. On this subject, Ortaş (2010) stated that 'elections are not just about gaining a vote. The first rule of democracy is 'equality' and 'rights.' Democracy does not mean just a simple election (majority rule). The vital thing is that following election interested parties are allowed to take part in decision making'.

This paper showed that organizational democracy was closely related to participation in management processes, democratic organizational climate, freedom (expression freedom and electoral freedom), and academics' right of organization, equality, qualification, and the concept of ethics. Based on these findings, it appears that academics thought that organizational democracy was mainly about participation in management processes. Participation is one of the most important processes in social life and is a vital concept in democratization. Yazic1 (2012) suggested that in organizations based on information, workers should participate in the decision-making process. Besides, Özdemir and Cemaloğlu (2000) said that in educational institutions, where participative management 
was applied, job satisfaction and other positive attitudes were observed.

In this study, academics found that OECD criteria such as faculties' creating funds through loans, independent spending of resources according to their aims, autonomous decision-making about permanent and contracted personnel, selection of personnel according to their merits, promotion of personnel according to their merits, decision making about salaries, and autonomy over dismissal of academics were poorly implemented and rarely deemed appropriate in Turkey. The main reason for academics finding criteria for autonomy was rarely applicable in Turkey was Law No. 2547. Under this law, state universities can determine their academic lesson plans only with the approval of CHET. The assignment of academic personnel is according to posts approved by the government, and universities have no authority to dismiss academics who do not reach the expected level of performance. Furthermore, state universities determine only the number of post-graduate students, not the number of undergraduate students.

This study found that Turkish academics perceived two categories of autonomy, managerial, and financial autonomy. They described managerial autonomy as accountability, universities making their own decisions, independence from political pressures, managing structure designed based on ethical principles, and remaining independent during elections. This finding was in line with the findings of Öztürk's (2004) thesis in which the description of Turkish Universities' Autonomy within the categories of Financial, Academic, and Managerial at State and Foundation universities was that "at universities, the more the institutional authority is distributed among the organs of the structure and the more the components of the universities participated in decision-making processes, the higher the level of managerial autonomy" (Öztürk, 2004).

In this study, it was seen that two different opinions exist among academics about financial autonomy. One was that universities were public institutions, and therefore, although they received financial resources from the government, universities had to be considered free to use such resources as appropriate. The other opinion was that universities would become more autonomous if they created their resources. In these two differing points of view, there was a common term, accountability.

The opinions of academics on financial autonomy was in agreement with the findings of the study by Kayrozz, Kinnear, and Preston (2001), titled 'The Application and Perception of Academics Working in the Field of Social Science At Australian Universities About Academic Freedom and Commercialization.' In that paper, it was concluded that academics had to change their research topic in order to secure financial support. One of the indicators of financial autonomy was the ability of universities to create their budget and their authority and responsibility for financial resources. The application of financial autonomy was very closely related to the development level and economic structure of society in which universities reside and the institutional culture of the country. Universities' authority over, and responsibility for, their resources were the supportive element of financial autonomy, especially in countries with a market economy, yet it could harm scientific freedom and could detrimentally affect the real function of universities in developing and undeveloped countries where social state politics were applied (Öztürk, 2006). From this point of view, it could be said that public resources finance universities. Besides this, they need opportunities to create their resources.

Aronowitz (1981) explained that with academic freedom came both responsibilities and difficulties. The main elements of academic freedom being learning and teaching freedoms. He underlined that academic freedom was not only applicable to certain individuals and groups but served to the benefit of all parties. For him, academic freedom posed specific responsibilities and difficulties, because unlimited freedom could create unregulated and idle freedom (i.e., anarchy). It might also cause a conundrum for the supporters of academic freedom. Here, the meanings of academic freedom and accountability could be understood as scientific studies performed by scientists using scientific criterion, instead of being oppressed by non-university (external) institutions. Scientific studies should never be oppressed by other institutions or by external processes (Aronowitz, 1981).

In the current study, it was concluded that academics in Turkey categorized academic freedom as instructional freedom, research freedom, and publication freedom. Academics also described instructional freedom, such as the ability to make their own decisions regarding the entire content of lessons, the instructional methods employed, and the assessment and evaluation criterion; and having academic freedom in the framework of ethical principles and participation of students in educational processes during their lessons. This finding was supported by the words of O'Brien (2000): 'the aims of a university cannot be met without giving respect to academic freedom. Scientists have to be free while teaching, scientists have to be free while researching, and scientists have to be free while publishing their studies. In this respect, Korkut (2001) expressed that, in the USA, even new assistants were accepted as 'experts in their field' and that they were able to give their lessons freely. In the current study, academics in Turkey described instructional freedom at an institutional level as evaluating 
their performance in lectures and the standardization of the content of lectures. However, some academics expressed concern that standardized lectures could create monotype students and information (Yazıc1, 2012).

Dölen (2010) expressed that the Second World War produced rapid scientific improvement. On the one hand, scientific information was used the war effort, so it was mostly 'top secret', whereas, on the other hand, scientists were led towards the studying of certain projects.

After the Second World War, the Cold War institutionalized confidentiality. These days, especially when studying the physical sciences, institutionalized confidentiality is a requirement for vital infrastructural investments. For this reason, those who finance research have started to determine the topics of studies, and as a result, the term 'industry-led science' has appeared. Both to provide confidentiality and to employ the skills of scientists piecemeal, the new method - puzzle method-was developed. For this method, huge projects or studies are divided into small pieces by the project manager and each small piece presented to researchers, with the financial support offered to those who study as requested. After that, the disparate small pieces would come together and become synthesized. In other words, the real picture was constructed, even where individual researchers were unaware of the wider picture. (Dölen, 2010, p. 117, researcher translation)

In this respect, it is vital in terms of academic freedom that financial institutions that support university research are prevented by law from interfering in the research process itself.

In the results of the current study, the main obstacles to organizational democracy identified were Central Bureaucratic Structure (Hierarchic Structure), lack of democratic culture in social structure, the electoral system at universities, legal obstacles (Law No. 2547), political pressure, arbitrary attitudes and applications, poor quality of managers, no professional management, poor instruction, and processes for academic appointment and promotion. These findings overlap with those of Özdemir, Yüksel, and Cemaloğlu (2003). In their study, it was found that academics felt they were only moderately involved in creating a compatible vision for faculties, encouraging personnel in using new teaching methods, and open and understandable communication among faculty management. Whereas, applications such as determining objective evaluation criterion, deciding managerial policies and strategies with the participation of academics were rare.

The literature supported the finding that academic freedom is sometimes limited by the society that would or should hinder this freedom. According to Çelik and Gür (2012), if academics believed that threats only came from outside universities, it would be a form of short-sightedness. If the academic community rebelled and spoke out during the speech of someone bound by an ideology, and if they then became silent during the speech of someone else bound to another ideology, it would be a kind of threat to academic freedom. The problem here was, in reality, a democratic problem, and academic freedom just came with democracy (Çelik \& Gür, 2012). In democratic structures, it is impossible to place intellectualism into molds. Academic freedom cannot live under the authority of sovereign ideology. The unique basis of intellectual life is criticism and criticism is the style of intellectual life (Grantham, 1999).

\section{Acknowledgments}

This paper was produced from the thesis - 'Academics' Opinions on Organizational Democracy and the Perception of Academic Freedom and Appropriate Level in Turkey' that was undertaken at the Educational Sciences Institute of Ankara University. I would like to thank Professor Dr. Ali BALCI, who provided extensive help in the planning, implementing, and reporting processes of the thesis.

\section{References}

Akerlind, G., \& Kayrooz, C. (2003). Understanding academic freedom: The views of social scientists. Higher Education Research \& Development, 22(3). https://doi.org/10.1080/758482627

Akın, F. (1998). $1933^{`}$ ten bu yana Türkiye'de üniversite düzenleri. Ankara Üniversitesi, Sosyal Bilimler Enstitüsü. Yayımlanmamış Yüksek Lisans Tezi.

Aronowitz, S. (1985). Academic freedom: A Structural approach. Educational Theory, 35(1). https://doi.org/10.1111/j.1741-5446.1985.00001.x

Balcı, A. (2001). Sosyal bilimlerde araştırma yöntem, teknik ve ilkeler, Ankara: Pegem A Yayıncılık.

Balcı, A. (2003). Kamu yönetiminde hesap verebilirlik anlayışı. In A. Balcı, A. Nohutçu, N. K. Öztürk, \& B. Coşkun (Eds.), Катu Maliyesinde Çağdaş Yaklaşımlar. Ankara: Seçkin Yayınları.

Balcı, A. (2005). Eğitim yönetimi terimleri sözlüğü. Ankara: Tek Ağaç Yayınları. https://doi.org/10.14527/9786053640745 
Bok, D. (1993). Universities in the marketplace: The commercialization of higher education, Princeton University Press, Princeton.

Brown, A. (2006). Academic freedom in Western Europe: Right or privilege? In E. Gerstmann, M. J. Streb, \& D. M. Rabban (Eds.), Academic Freedom at the Dawn of a New Century. California: Stanford University Press.

Brown, T. (2006). Confirmatory factor analysis for applied research. New York: Guilford Publications.

Çelik, Z., \& Gür, B. (2012). Akademik özgürlüğe kör bir üniversite özerkliği. Eğitime bakış eğitim. Öğretim ve Bilim Araştırma Dergisi, 8(23)

Çokluk, Ö., Şekercioğlu, G., \& Büyüköztürk, Ş. (2010). Sosyal bilimler için çok değişkenli istatistik: SPSS ve LISREL uygulamaları. Ankara: Pegem A.

Dölen, E. (2010). Türkiye üniversite tarihi özerk üniversite dönemi (1946-1981). İstanbul: İstanbul Bilgi Üniversitesi Yayınları

Emery, F. (1993). The new educational paradigm: An epistemological revolution. In M. Emery (Ed.) Participative design for participative democracy (second edition). Canberra: Australian National University (ANU) (Centre for Continuing Education (CCE)). Australian Capital Territory (ACT).

Grantham, M. (1999). Accountability in higher education: Are there 'fatal errors' embedded in current US policies affecting higher education. University of Minnesota Extension Service.

İlyas, İ. E. (2012). Yükseköğretimin finansmanı: Türkiye için model önerisi. Uzmanlık Tezi. Kalkınma Bakanlığı. Ankara: Sosyal Sektörler ve Koordinasyon Genel Müdürlüğü.

Jöreskog, K. G. (1993). Lisrel 8: Scructural equation modeling with simplis command language. Lincolnwood: Scientific Software International.

Kayrozz, C., Kinnear, P., \& Preston, P. (2001). Academic freedom and commercialisations of Australian universities perceptions and experiences of seocial science. University of Canberra.

Kepenekçi, Y. (2000). İnsan hakları eğitimi. Ankara: Anı Yayıncılık.

Kline, R. (2005). Principles and practice of structural equation modelling. New York: Guilford Publications.

Korkut, H. (2001). Sorgulanan yüksekögrretim. Nobel Yayınları. Ankara: Yayın No: 237

MacGee, W. R. \& Block, E. W. (1997). Academic tenure: An economic critique. Academic freedom and tenure: ethical issues. New York: Rowman \& Littlefield Publishers.

Miles, M. B., \& Huberman, A. M. (1994). Qualitative data analysis (2nd edition). Thousand Oaks, CA: Sage Publications.

Neave, G. (1980). Accountability and control. European Journal of Education, 15(1), 49-60. https://doi.org/10.2307/1503272

O’Brein, C. C. (2000). In defence of academic freedom. Academic Questions, 1. https://doi.org/10.1007/s12129-000-1020-1

O'Hear, A. (1988). Academic freedom and the university. In M. Tight (Ed.), Academic Freedom and Responsibility (pp.6-16). Buckingham, UK: SRHE \& OU press.

Olsen, J. P. (2007). The institutional dynamics of the European university. Higher Education Dynamics, 19. https://doi.org/10.1007/978-1-4020-5971-1_2

Ortaş, İ. (2010). Üniversitelerde seçim sistemleri-7: Üniversite yöneticilerinin önceden belirlenmesi kamu üniversitelerine uygulanabilir mi? Üniversite Seçim Sistemleri Yazı Dizisi. Rektörlük, Bölüm Başkanllğl, Dekanlık Seçimleri, Eleştiriler, Öneriler, Modeller. Cumhuriyet Üniversitesi.

Özdem, G., \& Sarı E. (2008). Yükseköğretimde yeni bakış açılarıyla birlikte yeni kurulan üniversitelerden beklenen işlevler. (Giresun ili örneği). Üniversite ve Toplum Dergisi. Cilt.8 Sayı.1

Özdemir, Ç., Yüksel, G., \& Cemaloğlu, N. (2003). Gazi üniversitesi ögretim elemanlart profili. Ankara: Gazi Üniversitesi İletişim Fakültesi Basımevi.

Özdemir, S., \& Cemaloğlu, N. (2000). Eğitimde örgütsel yenileşme ve karara katılım. Milli Eğitim Dergisi, p. 146.

Özipek, B. B. (2004). Akademik özgürlük. Nasll Bir Üniversite? C. C. Atakan (Ed.). Adapazarı: Değişim 
Yayınları

Öztürk, S. (2004). Türkiye'de üniversite özerkliğinin mali, akademik ve yönetsel boyutlarlyla devlet ve vakıf üniversiteleri için betimlenmesi. (Yayınlanmamış Doktora Tezi). Ankara Üniversitesi. Eğitim Bilimleri Enstitüsü.

Passmore, J. (1984). Academic ethics. Journal of Applied Philosophy, 1(1), 63-77. https://doi.org/10.1111/j.1468-5930.1984.tb00187.x

Rendel, M. (1988). Human rights and academic freedom. In M. Tight (Ed.), Academic Freedom and Responsibility (pp. 74-88). Buckingham, UK: SRHE \& OU Press

Sümer, N. (2000). Yapısal eşitlik modelleri. Türk Psikoloji Yazıları, 3(6), 49-74.

Tabachnick, B. (2001). Using multivariate statistics. USA: Allyn\& Bacon.

Taylor, J. (2001). The impact of performance indicators on the work of university academics: Evidence from Australian Universities. Higher Education Quarterly, 55(1), 42-61. https://doi.org/10.1111/1468-2273.00173

Tekeli, İ. (2012). Üniversite bilim ve Türkiye. V. Bilgin (Ed.). Ankara: Binyıl Yayınevi.

Tight, M. (1985). Academic freedom Re-examined. Higher Education Review, 18(1), 7-23.

Tight, M. (1988). Academic freedom and responsibility. USA: Open University Press.

Turner, J. (1988). The price of freedom. In M. Tight (Ed.), Academic Freedom and Responsibility. Buckingham, UK: SRHE \& OU Press.

Wissema, J. G. (2009). Üçüncü kuşak üniversitelere doğru. İstanbul: Özyeğin Üniversitesi Yayınları.

Yalçın, C. (2002). Akademik Özgürlük Üzerine Bir Değerlendirme. Eğitim Araştırmaları Sayı, 7, 112-125.

Yavuz, M. (2012). Yükseköğretim yönetiminde değişim ve Türkiye için alternatif model önerisi. Uzmanlık Tezi. Kalkınma Bakanlı̆̆ı. Ankara: Sosyal Sektörler ve Koordinasyon Genel Müdürlüğü.

Yazıc1, E. (2012). Türkiye'de üniversite algısı: Sorunlu bir dönüşüm. Üniversite, Bilim ve Türkiye, V. Bilgin (Ed.). Ankara: Binyıl Yayınevi.

\section{Copyrights}

Copyright for this article is retained by the author(s), with first publication rights granted to the journal.

This is an open-access article distributed under the terms and conditions of the Creative Commons Attribution license (http://creativecommons.org/licenses/by/4.0/). 